\title{
EDUCATIONAL PROCESSES IN CONDITIONS OF INCLUSIVE EDUCATION AND THEIR RESEARCH
}

\section{[PEDAGOGICKE PROCESY V PODMINKACH SPOLECNEHO VZDELAVANI A JEJICH VYZKUM]}

\author{
Anna Tomkova - Helena Hejlova
}

doi: 10.18355/PG.2018.7.2.3

\begin{abstract}
The paper presents the establishment, implementation, and evaluation of qualitative research on inclusive education at five public primary and secondary schools. The survey was focused on monitoring the educational processes of the school and their reflection by the pedagogical staff of the school, for which a semi-structured interview was developed as the main research method. The theoretical basis justifies the concept of inclusive education and the issues related to its implementation enhancing them by the philosophical view of the phenomena of sameness and otherness. The research verified the functionality of the research tool in monitoring the educational processes of the school, which can contribute to the longer-term monitoring of educational processes at school, to understanding their conditions in order to respond to the needs of the school. This may further support the school in its self-development in terms of inclusive learning. The research furthermore verified that inductively-deductive procedures of stationary theories in data processing can compare the strategies of individual schools and find out what is really important and significantly decisive for the inclusive education, as understood in the context of this contribution.
\end{abstract}

\section{Key words}

Inclusive education, educational processes, primary and secondary school, teacher, qualitative research

\section{Anotace}

Př́íspěvek referuje o založení, provedení a vyhodnocení kvalitativního výzkumu společného vzdělávání na pěti státních základních školách. Šetření bylo orientováno na sledování pedagogických procesů školy a jejich reflektování pedagogickými pracovníky školy, pro které byl vyvinut polostrukturovaný rozhovor jako hlavní výzkumná metoda. Teoretická východiska zdůvodňují pojetí společného vzdělávání a problematiku jeho realizace vysvětlovanou také $z$ filozofického pohledu na jevy stejnosti a jinakosti. Výzkumné šetření ověřilo funkčnost výzkumného nástroje při monitorování pedagogických procesů školy, což může přispět $\mathrm{k}$ dlouhodobějšímu sledování pedagogických procesů na škole, k porozumění jejich podmínkám, aby mohlo být reagováno na potřeby školy. Tím lze podpořit její seberozvoj z hlediska společného vzdělávání. Výzkum dále ověřil, že induktivně deduktivními postupy zakotvené teorie při zpracování údajů lze porovnat strategie jednotlivých škol a zjistit tak, co je pro společné 
vzdělávání, jak je chápáno $\mathrm{v}$ intencích našeho příspěvku, skutečně důležité a podstatně určující.

\section{Klíčová slova}

Společné vzdělávání, pedagogické procesy, základní škola, učitel, kvalitativní výzkum

\section{Úvod}

VČeské republice bylo Zákonem č. 561/2004 Sb. ${ }^{1}$, o předškolním, základním, středním, vyšším odborném a jiném vzdělávání zavedeno společné vzdělávání v hlavním vzdělávacím proudu a ve znění navazujících předpisů stanovena pravidla pro poskytování podpory žákům se speciálními vzdělávacími potřebami a žákům nadaným. Od školního roku 2016/2017 se implementace společného vzdělávání stala ve školách očekávanou realitou. Souvisejícím faktem je, že decizní sféra má zájem o odborné dlouhodobé monitorování změn $\mathrm{v}$ pedagogických procesech ve školách, které implementace společného vzdělávání nutně provázejí. To je současně výzva pro školy i pro odbornou veřejnost, které si musejí klást otázky: co společné vzdělávání je, o jaká východiska se opírá, jaká jsou s ním spjata očekávání, jakými pedagogickými procesy může nebo má být naplňována.

Problematika společného vzdělávání je spjata se sociálním a hodnotovým cílem, který je vevropském kulturním okruhu pocit’ován jako horizont nejbližšího sociálního vývoje společenství. Předpokládá ukončit všechny

formy diskriminace a utvářet společnosti vyznačující se koexistencí rozmanitostí. Škola má být např́ístě místem hledání podpor pro všechny děti, má být školou společného života s různorodostí, kterou běžný život přináší. To také znamená, že má procházet neustálými adaptacemi, diferenciacemi včetně variantnosti $\mathrm{v}$ pedagogické práci, má nabízet cestu úspěchu pro všechny žáky. Tato situace je svým způsobem v celospolečenském měřítku nová a je důvodné, abychom se dynamikou pedagogických jevů s ní spojených zabývali.

Cílem našeho př́spěvku je přispět $\mathrm{k}$ metodologii zkoumání tak složitých pedagogických jevů, kterými je reakce škol na zavedení společného vzdělávání. Je proto žádoucí a podstatné zabývat se i tvorbou validního výzkumného nástroje a postupy zpracování a interpretace údajů. Očekávaným př́nosem jsou poznatky o jednom z možných vstupů do reality pedagogické práce školy prostřednictvím zpracování subjektivně reflektovaných zkušeností a názorů učitelů a dalších pedagogických pracovníků, kteří v ní pracují, včetně vedení školy. Metodologický př́nos by měl spočívat ve zhodnocení postupů kvalitativního výzkumu využívajícího postupů zakotvené teorie pro zpracování reakcí škol na zavedení společného vzdělávání, které se odrážejí v edukačních procesech. Cílem př́spěvku je rovněž na príkladech ilustrovat výsledky doposud získané tímto prristupem a

1 Zákon č. 561/2004 Sb., o předškolním, základním, středním, vyšším odborném a jiném vzděláváni (školský zákon). [online]. [cit. 29. 8. 2018]. Dostupné z http://www.msmt.cz/dokumenty-3/zakon-c-561-2004-sb-o-predskolnim-zakladnim-strednimvyssim 
vyslovit tendence ve společném vzdělávání, které vykazuje vybraný vzorek základních škol.

\section{Teoretická východiska}

Společné vzdělávání se v hodnotové rovině dotýká jevů stejnosti a jinakosti, které jsou součástí našeho každodenního života. Vztaženo na osoby, oba jevy významně ovlivňují mezilidské vztahy. Porozumění důsledkům toho, jak a proč vnímáme něco jako stejné, tudíž pro nás příznivé, bezpečné, známé, domácí, blízké, anebo jako jiné, spíše nepříznivé, ohrožující, neznámé, cizí, vzdálené, je pro pedagogické procesy ve společném vzdělávání důležitější než v jiné organizaci vzdělávání a jeho jiném koncepčním rozvržení. Filozofické úvahy nad oběma jevy, v objasňování A. Hogenové (2000), je vnímají jako vzájemně komplementární, ale budící napětí. Podstatou tohoto napětí je přijetí stejnosti jako bezpečného zakořenění ve známém, v tom, na čem se podílím, co svým životem udržuji a rozvíjím. V této činnosti pak přesahuji sám sebe, nebot' ji vykonávám nejen pro sebe, ale i pro druhé. V pozitivním, tedy život podporujícím smyslu, se stejnost odráží v mém vědomí jako domov, jako bezpečí, jako možnost rozvíjení známého a sebeutváření díky podpoře ostatních, kteří mě přijímají jako svého. Tedy $\mathrm{v}$ rovnováze mezi přijímáním a dáváním, mezi přijetím a respektem $\mathrm{k}$ druhým. Když se tyto procesy z jakéhokoliv důvodu pokazí, pak zažíváme to známé, stejné, domácí jako př́iliš stísňující, rigidní, bránící v růstu. Tím, co může způsobit pokažení, může být rozkolísání kořenů nebo život bez přesahovosti. Z pozice stejnosti, zakořeněnosti, nahlížíme na jinakost jako na něco, co je určeno horizontem známého. Jinakost v pozitivním smyslu nabízí výzvu ke změně, je novostí, inspirací, může se stát novým pohledem na staré a známé. Převáží-li v ní ale pocit cizosti, výrazné odlišnosti, nepřijatelnosti a nezačlenitelnosti, pak je setkání s jinakostí ohrožením. Setkání s jinakostí, uvažuje dále A. Hogenová (tamtéž), způsobuje vynoření propasti, nicoty, která s sebou nese strach jako prvotní reakci. Proto musí být tato propast přemostěna. Překonán musí být přirozený strach, bud' zvědavostí nebo rozmýšlením, co jinakost představuje. Jinak se transformuje do potřeby druhého, jiného, ovládat, aby byl co nejpodobnější, co nejvíce stejný, aby se přizpůsobil. Další reakcí může být odmítnutí jinakosti ve smyslu jejího „zprůhlednění“. A. Hogenová se v tomto ohledu opírá o myšlenky Jaroslavy Peškové, že druhý, jiný, nesmí být ani zmenšen na nějaký dílčí znak ani ignorován jako neexistující, nebot', dodejme, se ztrácí jeho i naše lidská podstata. Pokud se tak stane, zůstáváme-li v úvahách o stejnosti a jinakosti, znamená to, že ani já si nejsem jist sám sebou, že o sobě a své existenci pochybuji. Filozofické myšlenky J. Peškové a A. Hogenové umožňují porozumět, že nejsme-li ukotveni a současně v přesahu, pak nás může cokoli rozkolísat, může být ničena naše svébytnost vyjádřená např́klad kulturou nebo aktuálním kontextem života. Jinakost je pak vnímána jako chaos a tedy ohrožení. Odpovědí je rigidnost, tedy nedůvodné lpění na známém, nebo naopak snadné podléhání manipulativním vlivům zvnějšku nebo proměnám vnitřního nastavení, které, dodejme, může být zvláště v průběhu dětství a dospívání výraznější. Naopak jsme-li ukotveni a jsme-li v přesahu, pak jsme otevřeni jiným vlivům jako potenciálně obohacujícím. Jádro je v tom, že jen 
vyrovnáváním mezi známostí a cizostí, mezi stejností a jinakostí, lze dosáhnout harmonie. Tato harmonie je vždy součástí dynamiky života, a proto je pružná. Ztratí-li tuto pružnost, pak se ztrácí i sama a my upadáme do boje mezi tím, co je stejné a jiné, často bez dostatečného rozlišování podstatného od nepodstatného. Zpravidla pak redukujeme druhého podle nějakého vnějšího nebo dílčího znaku - vnímáme jej jako nemoc (diagnózu), jako př́śslušníka určité skupiny, zpravidla jiné, nepochopitelné, nebezpečné apod. Jinakost nám vždy může ukázat nový pohled na věc nebo na sebe sama, i kdyby to bylo přes protivenství, přes srovnávání s odlišným. Je-li porušena harmonie ve směru $\mathrm{k}$ důrazu na stejnost, vždy vyvolá soupeření uvnitř systému, společenství. To je jev, se kterým se učitelé ve věkově relativně stejných trrídách základních i středních škol často potýkají. Je proto užitečné uvědomit si, že oba vzájemně spjaté jevy jinakosti a stejnosti vyvolávají emociální reakci, která je evolučně jistě starší než zdůvodněný a také jistě procítěný požadavek nediskriminovat.

V kontextu těchto úvah je společné vzdělávání snahou o vytvoření podmínek pro nastolení rovnováhy mezi stejností a jinakostí, byt' jakkoliv v pohybu a dynamice. Je taktéž neseno vírou, že budou-li se děti učit společně a žít společně $v$ komunitě školy, pak tyto jevy diskriminace a soupeřícího srovnávání pominou jako důsledek překonávání napětí mezi stejností a jinakostí. Požadavek společnosti vůči vzdělávání a škole zavést společné vzdělávání a předpokládat, že jinakost bude tímto aktem a zdůvodněním, že nikdo nesmí být diskriminován v žádném ohledu, vnímána jako obohacující a inspirativní, může fungovat jen tam, kde si je škola jistá svou prosociální hodnotovou koncepcí, kde je otevřená a stále hledající a promýšlející, nikoliv rigidní a vyžadující byt' jakkoli zdůvodněné přizpůsobení se svým zažitým postupům. Škola, která ví, co a proč dělá, která stále hledá odpovědi na vzdělávání dětí, jejichž různorodost se neustále proměňuje. Tehdy jinakost může být výzvou k objevování vně i uvnitř nás, to platí pro školu i lidi v ní.

Společné vzdělávání je tedy uvažováno v rovině koncepční a argumentační víme, proč jej chceme, v rovině hodnotové - je jednou z odpovědí na jevy stejnosti a jinakosti, které jsou přirozenou součástí života, v rovině prováděcí - hledáme cesty, jak jej v různých podmínkách uskutečňovat. Pro účely našeho př́spěvku je podstatná rovina prováděcí, kterou chceme zmapovat výzkumem na školách. $Z$ pohledu hodnotové roviny v současnosti nacházíme dvě ideje, které mohou ovlivňovat velmi podstatně rovinu prováděcí. Je to idea nediskriminace a idea naplnění potencí lidskosti cestou kvalitního, tj. obohacujícího vzdělávání, které umožní jedinci orientaci ve světě, v druhých i v sobě, a které je současně prosociálně zaměřeno, vyjádřeno tezí umět žít s druhými (Delors, 1996) ${ }^{2}$. V prováděcí rovině optikou koncepce vzdělávání „naučit všechny všemu“ se zdá, že obě ideje jdou proti sobě. Vzniká napětí mezi stejností - všem poskytnout kvalitní vzdělání, a jinakostí - vzdělávací potřeby žáků a studentů jsou různorodé, to je nutno respektovat. To ale nutí vyjádřit odlišnost, jinakost potřeb, a to, jak víme, vede k rozřad'ování. Do tohoto rozporu, který vyjadřuje napětí mezi danými jevy stejnosti a jinakosti,

2 DELORS, J. (ed.). 1996. Learning: The treasure within. Report to UNESCO of the International Commission on Education for the Twenty-first Century. Paris: UNESCO publishing. Dostupné z http://unesdoc.unesco.org/images/0010/001095/109590eo.pdf 
proniká zdůrazňovaný ohled na hodnotu nediskriminace. V této souvislosti je vysvětlující přednáška psycholožky Magdaleny Kohout-Diaz, přednesená na Pedagogické fakultě Univerzity Karlovy 27. 2. 2018. Nediskriminace je vnímána jako reakce na něco, co bylo poškozeno ve smyslu plného naplnění práva na vzdělávání včetně socializace do širšího společenského rámce. I proto je zaváděn pojem inkluze ve vzdělávání ve smyslu respektování odlišnosti hledáním adekvátních edukačních postupo̊. Koncept společného vzdělávání, jehož je inkluze součástí, vychází z nového pohledu na lidstvo, jak referovala $M$. Kohout-Diaz. Lidé jsou množinou snad nekonečna možných lidských uspořádání, konfigurací, které zakládá různorodost. Znovu je v tomto ohledu aktualizováno právo na vzdělání - chápeme jej v daném kontextu jako nárok na možnost tvořit si svůj život, naplnit své lidské potenciality až do přesahu sebe sama k druhým a k vyšším hladinám bytí. M. Kohout-Diaz právem na vzdělání obhajuje fakt, že např́íště má být proto očekávána i rozmanitost ve způsobech vzdělávání. Pojem inkluze v tomto konceptu je v současnosti založen na zkušenosti, že existují zranitelnější skupiny lidí, kterým musí být $\mathrm{v}$ důsledku toho věnována větší pozornost. Inkluze je pak požadavkem na to, aby bylo napraveno to, co škodí různorodosti vzdělávacích postupů. Od počátku 21. století se vzdělávací systémy snaží se s těmito pohledy na skutečnost vyrovnat. M. Kohout-Diaz s oporou o údaje publikované v roce 2003 Evropskou agenturou pro speciální potřeby a inkluzivní vzdělávání ${ }^{3}$ odkazuje na tři paradigmata ve vzdělávání, která jsou $\mathrm{v}$ různých kontextech často připomínána. Jedním z nich je maximální nediskriminace tím, že se nabízí jen jedna školní a vzdělávací cesta. Škola má být otevřena všem, speciální školy jsou výjimečné. Důsledkem jsou specializované programy pro žáky se speciálními vzdělávacími potřebami (napřr. Finsko). Druhé paradigma je realizováno v zemích, které nabízejí vícero škol a možnost volby (např. Česká republika). Třetí paradigma je realizováno dvěma samostatnými vzdělávacími systémy, běžným a specializovaným, jedná se tedy o model segregovaný (např. Francie).

Pro podporu inkluzivního vzdělávání existuje v mezinárodní evropské perspektivě už řada zásadních dokumentů. Požadavek nediskriminace je jedním z nejdůležitějších principů Všeobecné deklarace lidských práv a svobod (OSN, 1948) a mezinárodní Úmluvy o právech ditěte (OSN, 1989) $)^{5}$. M. Kohout-Diaz ve své přednášce připomněla, že na jednotlivé aspekty inkluzivního vzdělávání se od 90. let minulého století zaměřují významná jednání, z nichž vznikla řada strategických dokumentů od Světové deklarace vzdělání pro všechny z března 1990 (Jomtien, Thajsko) ${ }^{6}$, po dokument Boj proti segregaci na evropských školách prostřednictvím inkluzivního 
vzdělávání ze září 2017 (Rada Evropy) ${ }^{7}$. Tyto dokumenty reagují mimo jiné také na skutečnost, že koncepce vzdělávání, která inkluzivní postupy nezahrnuje, je nyní už dědictvím minulosti. Měla vyhovět požadavkům industrializace (Polechová, 2010) a více než na rozvoj potencialit člověka se soustředila na osvojování obsahu vzdělání. Pro současnost jsou už takové postupy nevyhovující i zhlediska dynamiky společenských a technologických změn. Zásadní přeorientování se na rozvíjení potencialit člověka, aby byl schopen naplnit své lidské možnosti, reagovat na rychlé civilizační změny a žít s ostatními, není tak jen altruistickou myšlenkou, ale je i požadavkem doby.

VČeské republice se o základním výkladu inkluzivního vzdělávání ve školském systému jedná od počátku nového milénia. Národní program rozvoje vzdèlávání v České republice (Bílá kniha) v roku 2001 zdůrazňuje nutnost „odstraňování segregovaného vzděláváni dètí se speciálními potřebami a jejich integrace do běžného vzdělávacího proudu se zachováním alternativni volby vzdèlávaci cesty těchto dètí a úkolu zabezpečení rovného př̀stupu ke vzdělávání pro všechny děti " (s. 57). Součástí Rámcového vzdèlávacího programu pro základní vzdèlávání (VÚP, 2005) se stala přiloha upravující vzdělávání žáků s lehkým mentálním postižením. Rámcový program vymezil také specifiku práce $\mathrm{s}$ mimořádně nadanými žáky. Většinové školy se svými školními vzdělávacími programy různě profilovaly, některé svými programy deklarovaly podmínky učení školního úspěchu pro všechny, jiné se dál prezentovaly svým konkrétním zaměřením, což z nich nadále činilo v jistém ohledu výběrové školy. Školy s různou erudicí řešily strategie, kterými budou své školní programy naplňovat, a různou měrou a kvalitou je také naplňovaly. Novelou zákona z března 2015, kterou se mění zákon č. 561/2004 Sb., o předškolním, základním, středním, vyšším odborném a jiném vzdělávání (školský zákon) se pro odbornou i laickou veřejnost idea společného vzdělávání více zreálňuje. Novela přináší především nové vymezení pojmu žák se speciálními vzdělávacími potřebami a nově pojem podpůrná opatření. „Ditétem, žákem a studentem se speciálními vzdělávacimi potřebami se rozumí osoba, která $k$ naplnění svých vzdělávacich možností nebo $k$ uplatněni nebo uživáni svých práv na rovnoprávném základě s ostatnimi potřebuje poskytnutí podpưrných opatření. Podpưrnými opatrenimi se rozumí nezbytné úpravy ve vzdèlávání a školských službách odpovídajicí zdravotnímu stavu, kulturnímu prostředi nebo jiným životním podmínkám dítěte, žáka nebo studenta. Děti, žáci a studenti se speciálními vzdělávacimi potřebami maji právo na bezplatné poskytování podpưrných opatřeni školou a školským zařizením." (Novela zákona č. 561/2004 Sb., In Sbírka zákonů č.82/2015, s. 1384). Ministerstvo školství, mládeže a tělovýchovy v Situačni zprávě o inkluzivním vzdělávání z roku 2015 deklaruje, že ,usiluje o systematické a intenzivní zavádèní inkluzivního vzděláváni a nastoleni rovného př́stupu ke vzděláváni všech dětí, žákủ a studentů (dále jen ,„̌áků“) v rámci České republiky. Cílem procesu je

$7 \quad$ Boj proti segregaci na evropských školách prostřednictvím inkluzivniho vzdělávání. Rada Evropy, 2017. Dostupné z https://rm.coe.int/fighting-school-segregationin-europethroughinclusive-education-a-posi/168073fb65 
nastaveni pozitivnich podminek pro vzděláváni všech žáků tak, aby při zabezpečeni adekvátnich podpưrných opatření, nezbytných pro zajištěni vzdělávacích potřeb každého žáka, bylo možné vzděláváni uskutečňovat prednostně $v$ hlavním vzdělávacím proudu. Plánování a realizace inkluzivního vzdélávání je proces, který se týká celého systému vzdělávání a všech žáků. Inkluzivni vzděláváni je třeba vidět jako rozvijejicí se koncept, kde maji témata rozmanitosti a demokracie stále větši význam." (2015, s. 3). Prováděcí opatření novely školského zákona z roku 2015 a další školskopolitické dokumenty podle našeho názoru nadále reagují především na odstraňování diskriminace ve vzdělávání žáků se speciálními vzdělávacími potřebami. Pojem inkluze je navíc v České republice konfrontován s pojmem integrace, který je od 80 . let 20 . století více užívaným ve smyslu včlenění žáka s odlišnými vzdělávacími potřebami do běžné výuky. U integrace se ovšem předpokládalo žákovo maximální možné přizpůsobení, byt' s pomocí různých pomůcek a úprav. Zaměňování pojmu integrace s pojmem inkluze přetrvává zvláště v myšlení a vyjadřování učitelů do současnosti. To je také jednou z metodologických obtíží níže referovaného výzkumu. M. Horňáková, která se tímto problémem zabývala v roce 2006 , vyjádřila učiteli reálně vnímaný vztah inkluze a integrace ve třech následujících podobách: inkluze se rovná integraci, inkluze je vylepšením integrace a konečně inkluze je zcela novou kvalitou $\mathrm{v}$ pohlížení na nutné podmínky vzdělávání žáků $\mathrm{s}$ různorodými vzdělávacími potřebami. Rozdíl mezi obsahem obou pojmů pro potřeby učitelské veřejnosti vyjádřila R. Votavová $(2013$, s. 1): „,...velmi zjednodušeně by bylo možné ř́ci, že integrace vyžaduje větši prizppưsobeni ditěte škole, zatímco inkluze se víc snaži přizpůsobit edukační prostředí žákům. “"

V Tematické zprávě ČŠI (Česká školní inspekce) z roku 2017 se konstatuje: „Ideálním stavem, ke kterému by měly školy směrovat, je situace, kdy škola systematicky identifikuje individuální potřeby dětí a žáků při vzdělávání, v prípadě potřeby spolupracuje s odbornými pracovišti, má vlastní strategii práce s dětmi a žáky s potřebou podpưrných opatření a tuto strategii naplňuje, sleduje výsledky dětí a žáků s potřebou podpưrných opatření a dbá o to, aby dosahovali maximálního učebního pokroku. Tam, kde je to vhodné z hlediska zájmu ditěte či žáka, pedagogové zvou $k$ procesu hodnoceni a plánování výuky dalši kolegy a externí odborniky. “ (s. 16-17). Také shrnutá pozitivní a negativní zjištění $\mathrm{z}$ implementace společného vzdělávání $\mathrm{v}$ roce 2016/2017 v ČR jsou ve zprávě ČŠI uvažována především pohledem na implementaci podpůrných opatření (s. 33-34).

Ve výkladu podstaty inkluzivního vzdělávání tak nadále dominuje zvýšená péče o znevýhodněné žáky nad výkladem inkluzivního vzdělávání jako vzdělávání pro všechny v jejich rozmanitosti a výkladem inkluzivní školy jako „ک̌koly společného života a rozmanitosti“ (Kohout-Diaz, 2018). Považujeme proto za důležité nahližet problematiku společného vzdělávání také $\mathrm{z}$ dalších úhlů pohledu, nejen $\mathrm{z}$ pohledu implementace podpůrných opatření. Přijetí ideje společného vzdělávání $\mathrm{v}$ českém školství je především otázkou přijetí jinakosti. Je třeba se zabývat také významností samotných pedagogických procesů, které se dějí př́i plánování, realizaci a hodnocení učení žáků a s jejichž nutnými změnami se potýkají učitelé a další 
pedagogičtí pracovníci, o kterých také mezi sebou i s rodiči a odborníky komunikují. S Školy jsou zavazovány se ptát, co ke svému vzdělávání potřebují žáci, kteří nebudou mít nárok na podpưrné opatření, a co potřebuje ke svému učení heterogenní tř́́da, která je složena z mnoha individualit, osobností, žáků s jedinečnými potřebami a podmínkami pro své učení.

S ohledem na cíle našeho př́spěvku nás zajímá vztah idejí společného vzdělávání, potažmo inkluze, k realitě práce školy. V této souvislosti se můžeme opř́ít o zkušenosti s vytvořením vzdělávacího programu Férová škola jako konceptu inkluzivní školy v prvním desetiletí tohoto století v České republice. Pavla Polechová je zpracovala ve studii Férová škola a inkluze (2010). Za podstatné pro tzv. inkluzivní školy, tedy školy realizující společné vzdělávání, považuje několik následujících rysů, s nimiž se ztotožňujeme. Škola vítá všechny žáky, což je argumentem pro spádovost, tedy pro povinnost školy přijmout všechny děti z okolí. Ve výuce je důraz kladen na proces, na hledání způsobů výuky vhodných pro aktuální složení žáků a jejich potřeby. Není to proto škola, která se nějak profiluje, není to škola se statusem. Naopak prochází neustálou adaptací, která vede $\mathrm{k}$ diferenciaci postupů a pedagogických podpor, k různorodosti pedagogické práce. Je to škola, která nabízí cestu k úspěchu všem žákủm. Musí proto rozumět i zdravotním znevýhodněním a postupům, jak je ve vzdělávání kompenzovat. Je to škola, která rozlišuje skutečné zdravotní znevýhodnění od sociokulturního, které ale nemá být už vnímáno jako znevýhodnění, ale jako součást přirození rozmanitosti. V tomto kontextu však M. Kohout-Diaz zmiňuje na základě zkušenosti z Francie potřebu pojmenovat situaci dětí ze zvláště chudých poměrů, jako chudé děti, nebot' tato situace je fakticky znevýhodňuje i ve vzdělávání. Postupně se vžívá teze ,neptat se, proč jsou obtíže, ale jaké jsou potíže a jaké podpory jsou třeba, aby byly zmírněny nebo odstraněny, a tyto podpory potřebnému dítěti dát“. Spolu s P. Polechovou zdůrazňujeme, že všeobecně přijatá definice inkluze ř́íká, že je to především proces, nikoli stav. Zkušenosti z našich i zahraničních škol, které bychom mohli označit za hodně pokročilé v procesu inkluze, ukazují podle Polechové, že takové školy si uvědomují nezbytnost stálého úsilí o zvyšování otevřenosti školy a obvykle samy sebe vidí na pouhém začátku této cesty. Kvalitní škola musí být schopna vyhodnocovat, na jaký rozsah rozmanitosti dětské populace je připravena, $v$ jakém rozsahu rozmanitosti může se všemi dětmi efektivně pracovat a tento rozsah zvyšovat.

V praxi se ovšem objevují problémy, které jsou se zaváděním společného vzdělávání spojeny a které je třeba při zkoumání pedagogických procesů na školách brát v úvahu. P. Polechová (2010) upozorňuje na jeden z nich. „Pro českého učitele a rodiče je ale zpravidla velmi obtižné prípustit, že různorodá, tedy heterogenni třída běžné velikosti, může pracovat $s$ maximálním efektem pro každé dítě, tedy efektivně a s vysokou mírou individualizace. Je to tím, že jednou $z$ nutných podminek efektivity $i$ individualizace je takový styl řizení třídy, který vyučujici ani rodiče sami nezažili. Existuji ale jak jednotlivé školy (včetně českých), tak i celé systémy, které dokazuji, že to možné je, tedy že je možné efektivně vyučovat v početných a zároveň heterogennich tř́dách. " (tamtéž, s. 5). Další problém se týká rozčleňování žáků a studentů do učebních skupin. Byl diskutován také 
po přednášce M. Kohout-Diaz na Pedagogické fakultě Univerzity Karlovy s výsledkem, že kategorizace žáků do skupin, která by mohla být vnímána jako proces jdoucí proti nediskriminaci, je přirozená a usnadňuje práci učitelům. Je ale třeba, aby byla funkční, aby nebrzdila proces individualizované podpory učení.

S ohledem na výše uvedená vymezení užíváme v našem textu nadále pojem společné vzdělávání, jehož je inkuzivní hledisko součástí. V souladu s autory zprávy ČŠI z roku 2017 společné vzdělávání chápeme jako „,vzdělávání všech dětí a žákủ společně v hlavním vzdělávacím proudu.“ (s. 3). Ve výzkumu jsme pojem společné vzdělávání upřednostnili záměrně před termínem inkluze $z$ důvodu možné záměny termínů inkluze a integrace. Je empiricky známým faktem, že v řeči některých učitelů obojí splývá (také viz výše $M$. Horňáková). Lze však předpokládat, že pokud učitelé rozumí společnému vzdělávání tak, jak je ideově vymezeno a zdůvodněno a jak jej v našem textu také chápeme, pak pojem inkluze odkazuje ve výpovědích učitelů na společné vzdělávání a lze oba pojmy vnímat jako synonymní ve smyslu odkazující na stejnou skutečnost.

\section{Výzkumné šetření reflektovaných zkušeností učitelů a dalších pedagogických pracovníků školy s pedagogickými procesy v podmínkách zavádění společného vzdělávání do základních škol.}

Otázka, která řídila výzkum a nastolila metodologické problémy, zněla: Jak zjistit a popsat reálnou reakci školy na změnu v organizaci a strategiích vzdělávání, která je nesena myšlenkou společného vzdělávání? Takto zformulovaná otázka je více metodologické povahy a zakládá explorativní polohu výzkumu. Jejím cílem bylo nalézt a ověřit výzkumnou cestu včetně výzkumného nástroje tak, abychom mohli vytvořit co nejvalidnější obraz reality práce školy. Výzkumná poloha zaměřená na zisk dat zachycujících proměnu pedagogických procesů školy pod vlivem zavedení společného vzděláván má povahu deskriptivní. Jejím cílem bylo na základě popisu práce školy a její reflexe pedagogy školy nalézt vzorce reagování škol na společné vzdělávání se zkušeností jednoho a půl roku. V těchto vzorcích nalézt významy, které jsou určující pro způsob, kterým škola přetváří podmínky své práce jak společné vzdělávání chápat a naplňovat.

Předmětnou oblastí výzkumu proto byly proměny pedagogických procesů a podmínek včetně výsledků učení subjektivně vnímaných a artikulovaných učiteli a dalšími pedagogickými pracovníky školy. Pedagogickými procesy vkontextu referovaného výzkumu rozumíme procesy ve vyučování, komunikaci mezi pedagogy školy o žácích i procesech a situacích, komunikaci vedení školy směrem k učitelům a dalším zaměstnancům školy. Bylo zřejmé, že pokud o nich chceme mluvit s učiteli, je třeba najít jejich jazyk, porozumět, jaká je jejich představa o těchto procesech, jak je reflektují, jak je pro sebe hierarchizují a s jakými hodnotami a vizemi je spojují, jak vnímají žáky (Korthagen et al., 2011). Touto optikou jsme identifikovali čtyřri rámce, o nichž se v souladu s konzultacemi s učiteli domníváme, že tvoří rozvržení učitelova uchopování jeho práce. Jsou jimi: průběh výuky a hodnocení, př́íprava na výuku, resp. plánování, zkušenosti 
se žáky, vize a hodnoty. Tyto rámce se posléze staly dimenzemi prvního kroku analýzy údajů.

Za základní metodologické rozvržení jsme zvolili kvalitativní výzkumný př́stup, který umožňuje postihnout sociální jev v jeho větší komplexnosti a dynamice. Protože jsme zkoumali především procesy, opírali jsme se jak při tvorbě hlavního výzkumného nástroje, tak při zpracování dat o postupy zakotvené teorie (Strauss - Corbinová, 1999; Švaříček - Šed'ová et al., 2007). Tato metoda stanovuje pravidla pro výzkum sociálních jevů strúdáním induktivních a deduktivních kroků. Je metodou budování teorie orientované na jednání a interakce (Strauss - Corbinová, tamtéž, s. 76), tedy na procesy, které nás zajímaly jako procesy pedagogické v rámci školy. Lze u nich sledovat změny v čase, a protože jsou záměrné, vedené určitým pochopením společného vzdělávání, mohou být reflektovány a lze o nich také hovořit. V intencích tohoto zdůvodnění jsme zvolili jako hlavní výzkumný nástroj polostrukturovaný rozhovor se třemi ohniskovými skupinami respondentů pedagogů na každé z pěti škol. Doplňkovou metodou bylo nestrukturované průběžné př́mé nezúčastněné pozorování klimatu školy a hospitační pozorování výuky některých učitelů na škole.

Tvorba výzkumného vzorku na úrovni škol byla záměrná, motivovaná. Při jejich výběru pro výzkum jsme se rozhodli ř́dit poznatkem, že ,není možné systémovou změnu realizovat ani naplánovat, aniž by existovaly školy, které ji na své úrovni modeluji a ukazují, co je možné. “ (Polechová, 2010). Vybírali jsme proto školy, které vědomě a cíleně hledají cesty, jak společné vzdělávání v podmínkách, které mají, naplňovat. Dalším kritériem výběru byla skutečnost, že procesům, které jsou sledovány, budeme lépe rozumět, pokud školy budeme znát ještě z jiných typů jejich návštěv. Těmi byly v našem př́padě pravidelné organizace studentských praxí, jejichž součástí byly naše hospitace ve výuce. Tento výběr spolu se znalostí školního vzdělávacího programu (ŠVP) umožnil jak lépe otevřít setkání s pedagogy, tak lépe porozumět, jak přemýšlejí, pracují a jak činnosti školy i své vlastní reflektují. Vybrali jsme tak pět státních základních plně organizovaných škol v Praze.

Vlastními participanty výzkumu byly tři skupiny pedagogů na každé škole. V každé skupině byli tři až čtyři lidé. Jednou ze skupin bylo vedení školy. Tvořil ji zpravidla ředitel nebo ředitelka, zástupci ředitele a př́padně další člen vedení nebo školní specialista. Vycházeli jsme zde z faktu, že členové vedení mají celistvější představu o směřování školy, o hodnotách i povaze procesů, které chtějí podporovat, a že mají přehled i o práci učitelů školy a mohou ji reflektovat komplexněji. Další dvě skupiny tvořili zvlášt' učitelé 1. stupně ZŠ a zvlášt' 2. stupně ZŠ. Do těchto skupin jsme zvali i př́ípadné asistenty. Oddělení učitelů obou stupňů zdůvodňujeme logikou opřenou zejména o věk žáků a o povahu práce s nimi, který podmiňuje i tendence v přijímání nebo odmítání odlišností, jinakostí. 1. stupeň ZŠ vše otevírá, různorodost přístupu ke všemu je přirozeně přijímaná a užitečná, každý si ověřuje své možnosti, každému žáku má být dopřáno naučit se různorodým učebním strategiím, aby si mohl řídit své učení sám. Žáci získávají první učební zkušenosti z řízeného a vědomého učení. Učitel učí ve trrídě více předmětů nebo všechny, lze proto předpokládat větší orientovanost na 
procesy. Na 2. stupni se vše rozvíjí a „upevňuje“, žák postupuje ve svých ověřených učebních strategiích, učí se strategiím novým, uchopuje svět v oborech lidské činnosti a zároveň provázaně, v souvislostech. Učitel učí jeden nebo dva předměty, lze uvažovat o větší orientovanosti na obsah.

Při tvorbě výzkumného nástroje jsme na základě analýzy předpokládané reakce škol na zavedení společného vzdělávání, identifikovali tři oblasti, v nichž se změna především může projevit: (1) Idea společného vzdělávání všech žáků se specifikou na 1. a 2. stupni, která se naplňuje především učitelovou vizí o smyslu učení (vyučování, vzdělávání a výchovy), učitelovými strategiemi a př́stupy k vyučování žáků (daného věku, daného předmětu na 2. stupni), učitelovými profesními potřebami jako podmínkami pro dobrý profesní výkon (jejich reflexí a iniciativou při naplňování) a vlivem kultury školy (co je pro školu z hlediska společného vzdělávání důležité). (2) Práce s heterogenní tř́ídou - ve smyslu různorodosti podmínek k učení u jednotlivců. Projeví se podporou učení každého žáka (tento požadavek vyplývá též z osobnostního pojetí žáka (Helus, 2009), diferenciací učení na úrovni plánů, cílů, řízení, obsahu, hodnocení a zpětné vazby. Je podmiňována vlivem věkových zvláštností, které v rámci výzkumu rozlišujeme podle členění v Rámcovém vzdělávacím programu pro základní vzděláváni (MŠMT, 2017) ve smyslu vzdělávacích období. Její součástí je také vliv dynamiky školní třídy a případných dalších školních skupin, jichž jsou žáci členy. V neposlední řadě je ovlivňována výsledky učení žáků, které ale můžeme zachytit ve výzkumu jen přes subjektivní reflexe učitelů (co si myslí, že se děje, co si myslí, že by se dít mělo, proč si myslí, že něco nejde).

(3) Spolupráce třídního učitele a dalších učitelů ve třídě mezi sebou a s asistentem. Tato oblast je sycena zejména osobnostními a profesními předpoklady pro spolupráci. Podstatný je i vliv kultury školy (pracovní klima, bezpečné prostředí atd. - tzv. lidské faktory), dále spolupráce se specialisty a $s$ rodinou.

Tyto oblasti jsme měli na mysli při postupném zpřesňování otázek v rozhovoru, který měl být strukturovaný s ohledem na tyto oblasti a zároveň by měl respektovat, jak učitelé o své práci uvažují. Měl proto ponechat dostatečný prostor pro jejich volné vyjádření a doplňování.

Při vývoji rozhovoru jako polostrukturovaného nástroje jsme respektovali nejprve dvě skutečnosti: (1) Vzdělávací procesy jsou centrální oblastí práce učitelů a školy, jsou vždy nějak reflektovány a něčím podmiňovány. (2) V lidské činnosti, tedy i v práci učitele, proces předchází koncept. S ohledem na ně byly ústřední linií rozhovoru procesy vzdělávání a z nich také byla odvozena jeho struktura, respektive tematizace komplexních vzdělávacích procesů těmi aspekty, ve kterých je sledovaný jev nejvíce projevován, a to řízení výuky, její příprava, resp. plánování, a hodnocení. S respektem vưči druhé zde uvedené skutečnosti a s vědomím, že koncept společného vzdělávání může být ve vědomí učitelů, kteří jej realizují, obsahově variantně sycen, jsme nekonceptualizovali prvou, a tedy úvodní tematickou oblast dotazováním na inkluzi nebo na společné vzdělávání, ale ptali jsme se na proměny procesů při vyučování, při jeho plánování a při hodnotících činnostech za podmínek, kdy jsou ve třídě různorodí žáci, tedy žáci, kteří potřebují různé podpory pro své učení. Následně jsme volili druhé téma, 
kterým byla orientovanost ve změně. Zde už byl koncept inkluze/společného vzdělávání pojmenován, ale nevysvětlován. Dotaz směřoval do osobního pojetí tohoto konceptu právě v souvislosti s procesy, nikoli s ideou a jejími hodnotami. Třetím tématem $\mathrm{v}$ pořadí rozhovoru bylo téma vize procesů a podmínek v souvislosti s vlastní školou. Protože bylo také odvozené od dotazování se na procesy, očekávali jsme pojmenování a vyhodnocení podmínek, které podporují a které naopak znesnadňují ideální procesy ve škole bez ohledu na to, zda se dotazovaní se společným vzděláváním ztotožňují nebo mají výhrady. Očekávali jsme výpovědi o profesních potřebách učitelů a představu toho, co je hodnotné pro rozvoj školy s ohledem na společné vzdělávání. Ve všech těchto tématech byl položen i dotaz na práci asistenta, at' už ve smyslu podmínky pro procesy, ve smyslu spolupráce pedagogických pracovníků školy nebo ve smyslu vlastní zkušenosti asistentů, pokud byli př́tomni. Celkový rámec rozhovoru byl nastaven na očekávání, že učitelé z titulu své profese chtějí učit co nejlépe, vnímají potřeby dětí a hledají cesty, jak jim při učení pomoci. Protože jsme chtěli získat data z reflexe podmínek pedagogických procesů, ptali jsme se $\mathrm{v}$ rámci vymezených témat rozhovoru také na to, co práci (pedagogické procesy) usnadňuje a ztěžuje, co se osvědčuje a co ne.

Struktura rozhovoru jako výzkumného nástroje zahrnovala $v$ hierarchii nejprve monitorovanou oblast, pro ni byly formulovány páteřové (klíčové) otázky, upřesněny byly konkretizačními otázkami, které jsme se pokusili vyjádřit $\mathrm{v}$ jazyce a myšlení učitelů tak, aby doplňovaly nebo rozšiřovaly otázku klíčovou.

\section{Př́íklad:}

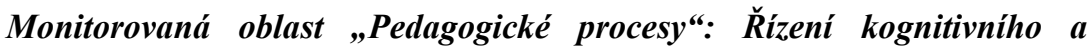
sociálně-emocionálního učení všech žáků ve třídě (ř́zení výuky především, podminky výuky odvozeně). Řizení učení jednotlivců (ev. skupin). ̌̌izení učení celé třídy s prechodem do výchovných (v užším slova smyslu) procesů, situací, zámérů a reakcí.

Kde lze v těchto procesech identifikovat reakci na změny $v$ RVP ZV (inkluze)? Zda a jak učitelé chápou nutnost změnit plánování, ř́zení a zpětnou vazbu s hodnocením ve tř́dè složené ze žáků s rưznorodými vzdělávacími potřebami - dèti se speciálními vzdělávacími potřebami, děti nadané, děti s lehkým mentálním postižením, děti sodlišným mateřským jazykem, děti bez adaptačních potiží.

Páteřvá otáżka pro oblast realizace - pro respondentskou skupinu učitelů 1. a 2. stupně:

Řídite učební situace z hlediska obsahu učení s ohledem na konkrétní žáky a na cíle výuky? Co se vám dař́? Co se vám nedaří, s čím máte problémy?

\section{Konkretizační otázky:}

- Při kterých situacích ve výuce si uvédomujete nutnost diferencovat, odlišovat učivo s ohledem na různost žák̉̊?

- Při kterých situacich ve výuce si uvědomujete nutnost diferencovat, odlišovat cíle učiva s ohledem na různost žáků? (kognitivni = učebni, sociální, vč. prožitkových a postojových, ev. $i$ psychomotorických) 
Páteřová otázka pro oblast plánování - pro respondentskou skupinu učitelů 1. a 2. stupně:

Plánujete učebni situace z hlediska obsahu učení sohledem na konkrétni žáky a na cíle výuky? Co se vám daří? Co se vám nedaři, s čím máte problémy?

\section{Konkretizační otázky:}

- Vycházíte při plánování z předpokladu (nutnosti) dosažení odlišných cílů rozdilných žáků?

- Jak plánujete učivo s ohledem na odlišnost, různost žáků?

- Jak využiváte při plánování předchozi zkušenost z konkrétních učebnich situaci?

- Jste při plánování cílů a učiva dostatečně připraveni předchozím studiem, př́p. vedením školy, nebo i vlastní aktivitou, ,,nutnosti“", resp. novou realitou, která se projevuje v procesu výuky? (cizinci, sociálně zvýhodněné i znevýhodněné skupiny žáků, žáci se speciálními potřebami)

- Jste vnitřně motivováni k plánování odlišných úrovní cílů i učiva?

- Plánujete odlišné cíle i úrovně učiva ve vztahu k možné pritomnosti asistenta ve výuce?

Proces vývoje otázek postupoval ve třech krocích: Vytvořili jsme páteřové otázky a k nim otázky konkretizační pro skupinu učitelů obou stupňů a pro skupinu vedení. Ověřili jsme formulaci otázek v předvýzkumu - společný rozhovor se skupinou osmi učitelů z praxe $z$ různých škol z 1. i 2. stupně získaných dostupným výběrem a rozhovorem $\mathrm{s}$ jednou ředitelkou školy. V této etapě jsme ověřili strukturu rozhovoru a formulaci otázek - obsahovou validitu, reliabilita by měla být zajištěna konkretizačními otázkami. Upravili jsme konkretizační otázky do znění, které používali respondenti v předvýzkumu a ověřili strukturu hlavních témat. Potvrdili jsme jako evokační část rozhovoru a současně jako první téma pedagogické, přesněji v této souvislosti výukové procesy.

Rozhovory proběhly ve školním roce 2017/18. V jeden den jsme provedli rozhovory se všemi třemi respondentskými skupinami na jedné škole, jejich pořadí bylo dáno podmínkami na škole, bylo proto různé, s vedením školy jsme však mluvili bud' před oběma učitelskými skupinami, nebo až jako s poslední skupinou. V rámci struktury rozhovoru jsme usilovali o to, aby otázky otevřely téma, chtěli jsme nechat proto co nejvíc mluvit respondenty.

Pro zpracování dat byly rozhovory přepsány a výroky kódovány klíčovými slovy nebo tezemi. Pro další úroveň zpracování jsme zvolili podobu případové studie, kazuistiky, zaznamenané vyprávěcím stylem s cílem zrekonstruovat realitu pedagogických procesů $v$ dané škole. Údaje $z$ rozhovorů ukázaly, že reakce školy na společné vzdělávání se tematizuje jejími čtyřmi aspekty: (1) Východisková předchozí zkušenost; (2) Vize školy a její sdílení; (3) Učitelovy vyučovací postupy v procesech společného vzdělávání; (4) Podmínky společného vzdělávání na škole - př́znivé, nepř́znivé vč. asistenta pedagoga. Tyto aspekty se staly kategoriemi pro zpracování kazuistik. Podstatné bylo ponechat autentické výroky, protože jejich zobecňování pedagogickými pojmy a tezemi by přestávalo mít 
vypovídací hodnotu pro vytvoření obrazu reálných pedagogických procesů. Údaje $\mathrm{z}$ rozhovorů byly $\mathrm{v}$ tomto prípadě doplněny ještě poznatky z pozorování a hospitací ve výuce.

\section{Příklad zpracování kazuistiky školy: \\ (1) Východisková předchozí zkušenost}

Škola vyjadřuje svou ideu jako „šance pro každého“ už dvacet let, myšlenka neni nová, dnes je však podporována, proto je to do určité míry lepší.

Škola vznikla sloučením dvou škol - prvostupňové a velké plně organizované. Vice než dvacetileté rozvíjeni vize osobou reditelky z prvostupňové školy, která od počátku svého založeni v polovině 90. let vstřebávala různé inovativni proudy, zvláště voblasti výukových strategií a metod. Tato malá škola také aktivnè vstupovala do tvorby koncepce RVP a ŠVP. Po sloučení dominoval tento duch malé školy - přšel celý 1 . stupeñ a vedeni se zaměřilo také na rozšiřvóni vize na celou školu a na propojování myšlenek mezi učiteli 1. a 2. stupně, učitelé byli cilleně vzděláváni v inovativnich př́stupech ke vzdělávání. Škola měla zkušenost z 1. stupně s dělením tř́d v paralelkách, s tzv. mixy. S touto zkušeností dále pracuje.

Podstatou vize byla za prvé užši spolupráce s rodiči, včetně snahy, aby rodiče rozuměli tomu, jak se uči a hodnotí, škola vítala rodiče, kteři si ji záměrně vybrali; za druhé integrování a rozvíjení všech dostupných inovací - práce sučivem, koncepce oborových didaktik, integrovaná tematická výuka, aktivizační metody, činnostní učení, komplexnějši vzdělávací programy typu Čtením a psaním ke kritickému myšleni (RWCT), atd. Vedení školy predpokládalo, že právě rüznorodé metody umožňuji diferenciaci.

Pravděpodobně díky výběru rodin, u kterých bylo vzděláni pomèrně vysokou hodnotou, se škole v minulosti nesetkala s větším počtem výrazně odlišných dětí, zejména voblasti mentálního postižení a psychiatrických potiží. Za přirozené považuji diferenciaci mezi běžnou populaci žákì, vč. cizinců, nadanějšich žáků a žáků se specifickými vzdělávacimi potřebami.

\section{(2) Vize školy a její sdílení}

Jádro vize je pokračovat v diferenciaci výuky pro žáky, kteři nemaji extrémně výrazné problémy. Di̊vodem je, že tito žáci neumožñuji vytvořit bezpečné a pracovní, ale i podnětné klima pro ostatni žáky ve třídě. Řešení by mohlo být $v$ tom, že by asistent s žákem vyžadujicím výraznou péči v př́padě potřeby odcházel do jiných prostor, ty ale ve škole chybí. Škola stále hledá strategie diferenciace, které by překonaly organizační, personálni a sociální překážky. Snaži se o ně na 1. i na 2. stupni.

Vize je stále přitomna a na poradách i při jiných přiležitostech připomínána a nyní už aktivně naplňována samotnými učiteli. Vedení zdůrazňuje význam pozitivní zkušenosti učitelì s diferenciací, včetně spolupráce s asistentem a speciálním pedagogem, př́padně psychologem. Škola účinně spolupracuje se speciálním pedagogem, který vzešel z jejich řad.

Vize do budoucna:

Vedení: Vytváret skupiny na ri̊zné činnosti v paralelkách i na 2. stupni.

Učitelé 1. stupně: Podržet dosavadni styl práce, použivané metody, vlídnou atmosféru a důvěru, kterou dává učitelům vedení, neztratit nadšení z tvořivé 
práce učitelů, rozvíjet spolupráci s rodiči a motivovat je pro spolupráci dobré pro ditě. Méně dètí ve třídě. Menši školu. Pozvednout profesi asistentů - jsou důležití.

Učitelé 2. stupně: Zachovat stmelujicí celoškolni aktivity - rituály a tradični akce - dèti se na ně dlouho připravuji, každý může vyniknout v něčem. Zachovat možnost, kdy učitel může samostatně něco vymyslet a zorganizovat. Přizpưsobovat organizaci potřebám diferencované výuky.

\section{(3) Učitelovy vyučovací postupy v procesech společného vzdělávání}

Vedení zdůrazňuje význam tvorby skupin žáků na různé úrovni vzdèlávacich potřeb, zkouši v různém ročniku různé modely tak, aby s nimi učitelé byli spokojeni, aby vyjadřovaly jejich možnosti a potřeby. Např. tzv. Barevných češtin se ve 2. ročníku účastni žáci z pěti paralelnich tříd, z nichž se tvoř́ osm skupin na jednu hodinu týdně, s jedním vyučujicím třikrát za sebou. Je třeba definovat tzv. základni práci v učivu a ročníku, se kterou se všichni vyučujici ztotožňuji. Společně metodicky plánují na úrovni ročníku. Tento základ se rozšiřuje bud' pro nadanějši žáky, nebo se opakuje (prodloužený výklad) pro pomalejší žáky.

Učitelé 1. stupně: Plánuji rámcově diferencovaně (více poznámek $k$ učivu, k činnostem, různorodé úkoly v projektech), maji promyšlené úkoly, které mohou dělat sami žáci, mají jasno, co musí dělat se všemi, uči děti, aby si práci braly samy. Vzávislosti na tom, jak jsou schopni učitelé mezi sebou schopni spolupracovat, diferencuji společně. Hodnotí slovně, soustředi se na pokrok jedince, $v$ tom je diferenciace přirozeně zabudovaná. Použivají kriteriálni hodnocení, které př́padně tvoři spolu se žáky. Žáci jsou vedeni $k$ sebehodnocení - pisemně. Jen někdy je třeba pojmenovat situaci, $k d y$ ditě potřebuje jinou míru podpory, pro ostatní. Oceňuji a vyvijeji strategii tzv. Berevných češtin, baví je to, je to tvořivé a oceňuji práci v týmu, zároveň konstatuji, že je to náročné. Od 1. ročníku zvykaji děti na promichávání jako na něco prirozeného.

Učitelé 2. stupně: Potřebuji znát děti při plánováni a zadáváni úkolů. Učitel angličtiny si dává cíleně pozor, aby nepojmenovával - lepši, horší, ale říká: Kdo je hotov, bere si dalši práci. Diferenciace výuky je jiná př́i novém učivu a při prohlubování. Rozšiřrováni učiva - např. v cizím jazyce obtižnějši slovíčka a více informací k tématu. Problémem je stejná známka za různý výkon. Učitelka občanské výchovy je zároveñ výchovnou poradkyní, zdůrazñuje neformálnost práce s plány pedagogické podpory, i żáci od počátku vědí, jak budou pracovat, samy si pro specifickou práci pricházejí. Hodnotí se hlavně individuální pokrok a respektuji se specifické potiže. V této souvislosti učitelka dějepisu naráži na meze diferenciace výuky - žáci pracují pod své možnosti, protože vidi, že jiným stači na dobrou známku nižši výkon. Diferenciace je zvlášt’ důležitá u hlavnich předmètù. U výchov, občanské výchovy apod. to tak neni vnímáno, proto na tyto hodiny také nechodí asistent, což je podle učitelů často škoda.

Asistent je někdy zapojen i do výuky - tam, kde jsou skupiny, na 2. stupni je zatím malá zkušenost s asistentem, někteři učitelé by uvitali asistenta pro tř́du, který by tam byl stále. Učitelé zdůrazňuji, že důležitá je osobnost asistenta a nastaveni spolupráce. 


\section{(4) Podmínky společného vzdělávání na škole - příznivé, nepřiznivé vč. asistenta}

Asistent je kdispozici pro zajištěni procesu výuky, s učiteli obvykle neplánuje, je-li potřeba se domluvit, děje se tak průběžně krátce během výuky. Je využiván i pro doučování. Zkušenost s asistenty maji spiše učitelé na 1. stupni, je obvykle k dispozici žákưm i učiteli tam, kde je potřba. Na 2. stupni je působení asistenta organizačně složitější, zkušenosti s ním mají spiše učitelé základnich predmètü. Asistent je ve třídě především většinou kžákovi, učitelé komunikuji krátce s asistentem jen ohledně daného žáka. Podle vedení školy učitelé považuji asistenty spiše za pomocné sily, nedávají jim pravomoci. Na 2. stupni je přtomnost asistenta u žáka podle zkušeností učitelů vnímána žáky jako ponižujicí. V reakci na to žákovský parlament natočil film o asistentech, který by měl tento postoj změnit. Také někteři rodiče obtižněji prijizimaji asistenta ve třídě svého ditěte, napřiklad si $i$ stěžovali, když asistent jejich dítě napomínal nebo mu pomáhal. Jsou to sice výjimky, ale výrazné. V roli asistentů hlavně na 1. stupni působí $i$ studenti učitelství, jejich čas je ale omezen studiem.

Nepríznivé podminky:

Administrativni zátěž, dalši práce, kterou učitelé vyhodnocují jako neučitelskou na úkor promýšleni hodiny a přemýšlení o dètech. Hrozí vyhoření. Chybi dostatek doporučení, co asistent může a nemůže dělat - na 1. stupni.

Nedostatek materiálnich podmínek pro vnitřni diferenciaci - víceúrovňové zpracování obsahu v učebnicich a námètech. Pomohlo by intenzivnější metodické doporučení a vedeni - učebnice a pracovni listy různé úrovně.

Málo asistentù.

Podmínky pro vstup žáků do speciálních škol se hodně zpřisnily, ale není možno integrovat všechny. Děti, které nabourávají výuku a jsou napr. $i$ agresivni zhoršuji bezpečnost ve třídě a ohrožuji pracovní klima.

Nevzdělanost a neinformovanost rodičů zvlášté s ohledem na děti s výraznějši odlišností (mentální a s poruchami chováni) ohrožuji naplňování vize školy.

Psychologa a speciálního pedagoga nelze zaplatit na plný úvazek.

Práce asistentů neni zaplacena adekvátně a není doceněna.

Děti s hraničním intelektem jsou na 2. stupni spiše neštastné, a to i pres ochotu ostatních žáki pomoci nezvládaji učivo, dalši cizí jazyk, cítí se vyčleněni, presestože to třída nedělá.

Přiznivé podmínky:

Podař́-li se, že je symbióza lidí, učitelé se společně domluví na řadě vnitřně diferencovaných aktivit, napřr. výuka vedená dvěma učiteli, Barevné češtiny na 1. stupni, spolupráce se speciálním pedagogem.

Rozvoj elektronických opor (tablety, PC) ve třídě, i když učitelé zvažují $i$ rizika, napr. by práce žáka na PC mohla vyvolávat nepochopeni ostatních, jako závist, vyčlenění, dokonce potřebný žák sám tuto podporu odmitá, aby se necitil vyčleněn.

V následující úrovni zpracování jsme na základě kazuistik odrážejících reflektovanou zkušenost škol dále abstrahovali do tzv. vzorce uvažování škol 
o společném vzdělávání. Jeho účelem bylo zachytit podstatné jevy, které změnu pedagogických procesů na škole spojenou se zavedením společného vzdělávání ohraničují. Analytickým popisem v kazuistikách jsme identifikovali čtyřri kategorie, které zachycují jevy podstatné pro záznam reakce školy na zavedení společného vzdělávání: (1) Reflexe zkušenosti se společným vzdělávání před zavedením změny; (2) Reflexe reakce školy na změnu; (3) Reakce na př́tomnost různorodých, zejména výrazněji odlišných, žáků a reflexe zkušenosti s nimi; (4) Výsledný postoj ke společnému vzdělávání cca po 1,5 roku od zavedení změny. Cílem vzorce bylo pochopit pedagogické procesy a jejich podmíněnost. Očekávali jsme, že srovnáním reflektované zkušenosti a sdělovaných postojů lze odhadnout tendence a potřeby jednotlivých škol. Pro toto srovnání jsme stanovili pro vzorec každé školy stejnou otázku: Co je podstatného v obsahu zkušenosti (vlastní vzorec) a co ji nejvíce ovlivnilo (údaje pro srovnávací analýzu vzorců).

\section{Př́́klad:}

\section{Vzorec uvažování školy o zavedení společného vzdělávání}

1. Reflexe zkušenosti se společným vzdělávání před jeho zavedením $v r$. 2016/17

Otevřenost ve smyslu „šance pro každého“ s dlouhodobou zkušeností začleňováni inovativních programů a postupů konstruktivistického učení vnímaného také jako prostředí pro diferenciaci. Škola upřednostňovala výběr žáků z rodin, které byly schopny se školou spolupracovat a mély vysokou hodnotu vzděláváni. Dlouhodobějši je zkušenost s vytvářením skupin mimo třidy v rámci ročníku pro češtinu.

2. Reflexe reakce školy na změnu danou společným vzděláváním

Změna umožnila pokračovat v diferenciaci a ověrování dalšich postupư $v$ předmětech a ročnících. Škola však neni prostorově vybavena na př́padnou samostatnou práci asistenta s žákem. Hledaji se strategie, které by překonaly organizační, personálni a sociální překážky. Učitelé si definují základní učivo, $k$ němu přidávaji nebo ubírají. Diferenciace tedy probíhá nejen metodami a tempem, ale i učivem.

3. Reakce na prítomnost různorodých, zejména výrazněji odlišných, žáků a reflexe zkušenosti s nimi

Učitelé považují za přirozené diferencovat postupy, učivo i hodnocení pro žáky s lehčimi formami speciálních vzdělávacích potřeb, pro nadané a cizince. Hodnocení je založeno na pokroku jedince, klasifikace proto nevyhovuje. Jako stmelující oceňují celoškolni aktivity a tradice školy.

4. Výsledný postoj ke společnému vzdělávání cca po 1,5 roku od jeho zavedeni

Škola se společným vzděláváním souhlasí, ale považuje to za náročné. Záleži hlavně na souhře lidí, aby diferenciace byla smysluplná. Nepř́jemná je nařizená spádovost. Dřive si škola cenila rodin, které si ji vybraly a chtěly spolupracovat pri vzdělávání svých dětí. 
Srovnáním vzorců pěti základních škol se nám podařilo potvrdit, že pro reakci školy na zavedení společného vzdělávání jsou tyto čtyři kategorie vzorce skutečně zásadní. $V$ této úrovni můžeme také porovnávat, jak školy na zavedení společného vzdělávání bezprostředně reagovaly. Lze tedy nalézt určité tendence $\mathrm{v}$ jednání, které uvádíme bez jejich hierarchizace: tendence $\mathrm{v}$ hledání strategií pro kognitivní rozvoj žáků s důrazem na sociokonstruktivistické metody výuky, zejména $\mathrm{v}$ hledání postupů při diferenciaci výuky při expozici nového učiva a jeho upevňování v klíčových předmětech (český a cizí jazyk, matematika); podpora učitelů při individualizaci včetně hledání variant formativního hodnocení; zvýrazněná nutnost péče o bezpečné a podnětné prostředí ve třídě; tvorba nových učitelských týmů školy, zahrnujících $i$ asistenty pedagoga, které řídí a realizují pedagogické procesy včetně cílené komunikace uvnitř školy a se specialisty vně školy; tendence hledat nová organizační uspořádávání výuky pro různě sestavované učící se skupiny nebo pro konkrétní učební obsahy (typicky pro český a cizí jazyk, také v podobě nabídky volitelných předmětů reagujících na zájem žáků); tendence tvořit prostupné učící se skupiny vycházející z průběžného sledování, co žáci potřebují a jak postupují ve svém učení; tendence podporovat sociální rozvoj žáků také organizačně tvorbou učících se skupin napříč ročníky nebo napříč paralelními třídami v ročníku; tendence cíleně hledat podpory nejen pro žáky se speciálními vzdělávacími potřebami, ale i pro žáky s odlišným mateřským jazykem, prípadně $\mathrm{i}$ kulturou, a pro žáky nadané. Ukázalo se také, že školy, které byly už před zavedením společného vzdělávání orientovány na žáka jako rozvíjející se osobnost nejen v kognitivní oblasti, navazují na své předchozí strategie a rozšiřují je. Školy, které byly více zaměřeny na výkon, s čímž je spojena jistá výběrovost žákủ, nyní strategie společného vzdělávání hledají obtížněji. Potvrdilo se rovněž, že i školy, které mají zkušenosti se společným vzděláváním dlouhodobější, vnímají jeho realitu skutečně procesuálně, samy sebe vidí v neustálém procesu přizpůsobování se složení žáků vyvíjením funkčních strategií individualizace a diferenciace výuky na pozadí socializace všech žáků.

V další, již třetí, úrovni zpracování jsme využili formu paradigmatického modelu ${ }^{8}$, který nabízí zakotvená teorie (Strauss - Corbinová, 1999). Zvolili jsme jej proto, že systematizuje pohledy na určený jev, jehož povaha je především sociální a jako taková je podmiňována. Naším cílem bylo podívat se na sledovaný jev nejen z pedagogického hlediska, ale i z hlediska jeho širších sociálních podmínek. Upřesnit tak, jaké podmínky jsou funkční pro pedagogické procesy ve společném vzdělávání.

V této úrovni zpracování jsme se pokusili o modelování vzdělávání na školách po implementaci společného vzdělávání. Ústředním jevem byla otázka Jak učitelé a školy zvládají nové požadavky na svou práci po implementaci společného vzdělávání. Do definovaných oblastí paradigmatického modelu, kterými jsou př́ičinné podmínky, strategie jednání

$8 \quad$ Paradigmatický model je vymezen jako model soubor vztahů, které blíže určují sledovaný jev. V zjednodušeném schématu s ním pracují Strauss - Corbinová (1999, s. 72): příčinné podmínky - jev - kontext - intervenující podmínky - strategie jednání a interakce následky. 
a interakce, kontext, intervenující podmínky a následky, jsme vyabstrahovali podstatné poznatky z ,,vzorce uvažování školy o společném vzdělávání“.

\section{Příklad:}

\section{Pedagogické procesy školy optikou paradigmatického modelu}

Jev: Jak učitelé a školy zvládají nové požadavky na svou práci po implementaci společného vzdělávání.

Př́činné podminky: Zavedení společného vzdělávání a spádovosti.

Kontext: Škola prijímajici všechny žáky, vitajici rodiny se zájmem její program a o vzdělání vůbec.

Intervenujici podmínky: Sloučeni dvou škol, původně prvostupňové, facilitační vzhledem kžákovi, a školy plně organizované výkonově orientované.

Strategie jednání a interakce: Škola cíleně uplatňuje inovativní postupy, aby výuka byla pestrá a aktivizovala žáky při učení kognitivním i sociálním, zvláště na 1. stupni. Vedení podporuje komunikaci mezi 1. a 2. stupněm.

Následky: Vylad'ování personálních, organizačnich a ekonomických podminek pro vyvijené strategie, které podporuji společné vzdělávání, jasná vize managementu a podpora učitelì při společném vzdělávání.

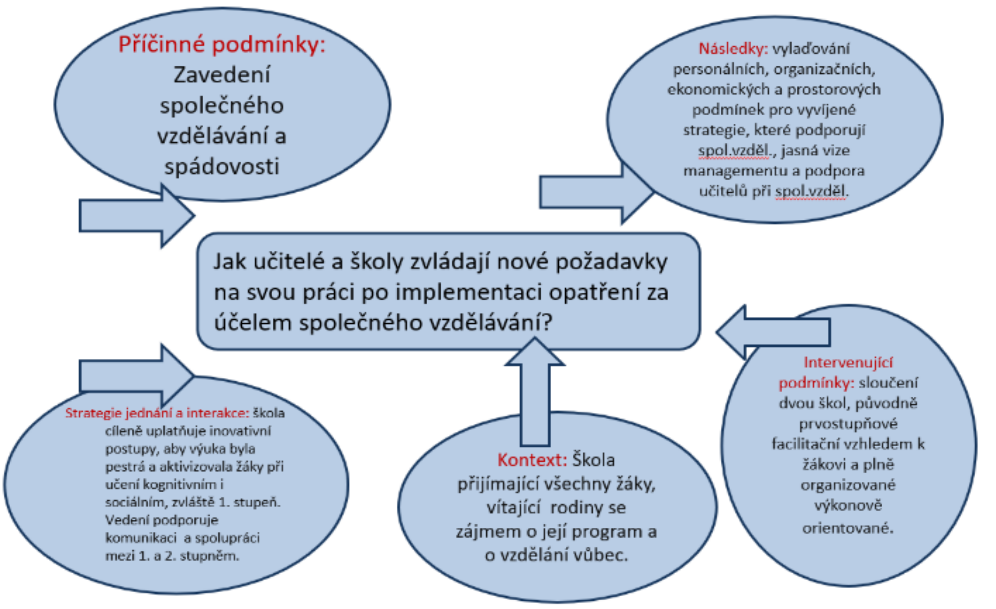

\section{Obrázek 1: Příklad využití paradigmatického modelu}

Účelem zpracování paradigmatického modelu pro každou ze škol je ověřit způsob, jak identifikovat zejména kategorii intervenujících podmínek pro společné vzdělávání, když kategorie příčinných podmínek bude nadále v těchto modelech sycena proměnlivostí ve složení žáků a tedy nutností reagovat na jejich různorodé potřeby. Je třeba vidět, že i na této úrovni se jedná o neustálý proces monitorování proměnných a zvažování účinných strategií vzdělávání, v paradigmatickém modelu zobrazených v kategorii následků skutečných i potencionálních. 


\section{Závěr}

Výzkum prokázal využitelnost použitých kvalitativních výzkumných postupů pro sledování tak složitého jevu, kterým je reakce školy na zavádění společného vzdělávání. Umožnil pochopit, které intervenující podmínky především mohou ovlivňovat tuto reakci. Ověřil funkčnost výzkumného nástroje při monitorování pedagogických procesů školy, což může přispět $\mathrm{k}$ dlouhodobějšímu sledování pedagogických procesů na škole, k porozumění jejich podmínkám, aby mohlo být reagováno na potřeby školy. Tím lze podpořit její seberozvoj z hlediska společného vzdělávání. Výzkum dále ověřil, že induktivně deduktivními postupy zakotvené teorie při zpracování údajů lze porovnat strategie jednotlivých škol a zjistit tak, co je pro společné vzdělávání, jak je chápáno v intencích našeho příspěvku, skutečně důležité a podstatně určující. Pro decizní sféru by tento monitoring mohl ukázat, jak dále vylepšovat vnější podmínky práce školy tak, aby se v důsledku toho mohla každá škola rozvíjet jako škola společného vzdělávání. Náš výzkum zahrnul pětici základních škol, které v tomto ohledu přistupují $\mathrm{k}$ úkolu zavést společné vzdělávání aktivně. Jejich zkušenost, kterou zde uvádíme jen na dílčích vybraných příkladech, svědčí o tom, že podstatné pro společné vzdělávání je neustálé hledání funkční podoby pedagogických procesů vzhledem k žákům, že je tyto školy nacházejí a mohou inspirovat další. Je však zřejmé, že bude třeba se do těchto škol vracet a zároveň monitorovat další školy, abychom zachytili co největší varietu podmínek a vzdělávacích strategií a potvrdili tendence ve společném vzdělávání v České republice. Získaná data se mohou stát také zdrojovými pro založení kvantitativní polohy výzkumu a formulaci hypotéz. V neposlední řadě může být referovaný výzkum a jeho výsledky využity pro teorii společného vzdělávání a obecné didaktiky.

\section{Bibliographic references}

HELUS, Z. 2009. Dite v osobnostnim pojeti. Praha: Portal. ISBN 978-807367-628-5.

HOGENOVA, A. 2000. K fenomenologii ,domova a jinakosti“ in ELOGOS. ELECTRONIC JOURNAL FOR PHILOSOPHY, vol. VII. ISSN 1211-0442. https://e-logos.vse.cz/index.php?article=222

HORNAKOVA, M. 2006. Inkluzia - nove slovo, alebo aj novy obsah? in Efeta - otvor sa : casopis pre postihnutych a ludi, ktori im chcu pomahat, vol. 16, n. 1, pp. 2-4. ISSN: 1335-1397.

KOHOUT-DIAZ, M. 2018. Inkluzivni vzdelavani z globalni perspektivy a jeho provadeni ve Francii. Prednaska prednesena na Pedagogicke fakulte Univerzity Karlovy. Praha 27. 2. 2018.

KORTHAGEN, F. et al. 2011. Jak spojit praxi s teorii: Didaktika realistickeho vzdelavani ucitelu. Brno: Paido. ISBN 978-80-7315-221-5. Narodni program rozvoje vzdelavani v Ceske republice (Bila kniha). 2001. MSMT CR. ISBN 80-211-0372-8.

POLECHOVA, P. 2010. Ferova skola a inkluze [online]. [cit. 2. 3. 2016]. Available online:

http://www.ferovaskola.cz/data/downloads/příspěvek\%20Polechova.pdf. 
Situacni zprava o inkluzivnim vzdelavani. 2015. MSMT CR. [online]. [cit. 29. 8. 2018]. Available online: http://www.msmt.cz/vzdelavani/socialniprogramy/situacni-zprava-o-inkluzivnim-vzdelavani

Spolecne vzdelavani ve skolnim roce 2016/2017. Tematicka zprava. 2017. Praha, CSI. [online]. [cit. 29. 8. 2018]. Available online:

https://www.csicr.cz/cz/Aktuality/Tematicka-zprava-Spolecne-vzdelavanive-skolnim-ro

STRAUSS, A. L. - CORBINOVA, J. M. 1999. Zaklady kvalitativního vyzkumu: postupy a techniky metody zakotvene teorie. Brno: Sdruzeni

Podane ruce. ISBN 808583460X.

SVARICEK, R. - SEDOVA, K. et al., 2007. Kvalitativni vyzkum

v pedagogickych vedach. Praha: Portal. ISBN 978-80-7367-313-0.

VOTAVOVA, R. 2013. Rozdilny vyznam pojmu integrace a inkluze. [cit. 29. 8. 2018]. Available online:

https://clanky.rvp.cz/clanek/c/SSC/17243/ROZDILNY-VYZNAM-POJMUINTEGRACE-A-INKLUZE.html/.

Ramcovy vzdelavaci program pro zakladni vzdelavani. 2017. Praha: MSMT. [online]. [cit. 3. 8. 2018]. Available online: http://www.nuv.cz/t/rvp-prozakladni-vzdelavani

PhDr. Anna Tomkova, Ph.D.

Department of Pre-primary and Primary Education, Faculty of Education, Charles University in Prague

Magdalény Rettigové 4, 11639 Prague 1

Czech Republic

anna.tomkova@pedf.cuni.cz

PhDr. Helena Hejlova, Ph.D.

Department of Pre-primary and Primary Education, Faculty of Education, Charles University in Prague

Magdalény Rettigové 4, 11639 Prague 1

Czech Republic

helena.hejlova@pedf.cuni.cz 